\title{
Isolation and characterization of $\alpha$-amylase from marine Pseudomonas sp. K6-28-040
}

\author{
Jianguo Liu ${ }^{1 *}$, Zhiqiang Zhang ${ }^{1}$, Hu Zhu ${ }^{1}$, Hongyue Dang ${ }^{1}$, Jianren $\mathrm{Lu}^{2}$ and Zhanfeng Cui ${ }^{3}$ \\ ${ }^{1}$ Center for Bioengineering and Biotechnology, China University of Petroleum (East China), Qingdao 266555, People's \\ Republic of China. \\ ${ }^{2}$ School of Physics, Manchester University, Manchester M60 1QD, UK. \\ ${ }^{3}$ Department of Engineering Science, University of Oxford, Oxford OX1 3PJ, UK.
}

Accepted 25 February, 2011

\begin{abstract}
The a-amylase of marine Pseudomonas sp. K6-28-040 was purified through a series of three steps and the purity of enzymes was checked by sodium dodecyl sulfate-polyacrylamide gel electrophoresis. The results showed that, the enzyme was purified 4.7-fold with a specific activity of $134.6 \mathrm{U} / \mathrm{mg}$ protein and a yield of $44 \%$. When it was subjected to SDS-PAGE, a single band near $58 \mathrm{kDa}$ appeared. The optimum temperature and $\mathrm{pH}$ were $50^{\circ} \mathrm{C}$ and 7.0 , respectively. The addition of $\mathrm{Ca}^{2+}, \mathrm{Mn}^{2+}$ and $\mathrm{Co}^{2+}$ could improve the enzyme activity, while $\mathrm{Cu}^{2+}, \mathrm{Hg}^{2+}, \mathrm{Fe}^{3+}$ and $\mathrm{Al}^{3+}$ decreased the activity. The enzyme was inhibited by ethylenediaminetetraacetic acid (EDTA), ethylenebis(oxonitrilo)]tetra-acetate (EGTA), SDS and dimethyl sulfoxide (DMSO), but was not affected by phenylmethane-sulfonyl fluoride (PMSF) and 1,4-dithiothreitol (DTT). $K_{\mathrm{m}}$ and $V_{\max }$ values of the purified enzyme for soluble starch were $1.73 \pm 0.3 \mathrm{mg} / \mathrm{ml}$ and $1.24 \pm 0.02$ $\mathrm{mg} / \mathrm{ml} / \mathrm{min}$, respectively. The degradation ability of wild type $\alpha$-amylase on starch granules was examined by thin layer chromatography. The final purified enzyme had an isoelectric point of 7.5-7.8 and $\alpha$-helix of $28 \%$, $\beta$-sheet of $32 \%$ and random coil of $40 \%$.
\end{abstract}

Key words: a-Amylase; Pseudomonas sp., purification, enzyme characterization.

\section{INTRODUCTION}

The enzyme, $\alpha$-amylase (E.C 3.2.1.1) catalyses the hydrolysis of $\alpha-D-(1,4)$ glycosidic linkages in starch components and related carbohydrates. It is a key enzyme in the production of starch derivatives and also widely used in food, textile, paper, detergent, clinical, pharma- ceutical and other industrial fields (Bhat, 2000; Fogarty and Kelly, 1990; Kandra, 2003; Kirk et al., 2002). In the last decades, there has been lots of research on the

${ }^{\star}$ Corresponding author. E-mail: jianguoliu@upc.edu.cn Tel: +86 53286981566.

Abbreviations: EDTA, Ethylenediaminetetraacetate; EGTA, ethylenebis(oxonitrilo)]tetra-acetate; SDS, sodium dodecyl sulphate; DMSO, dimethylsulfoxide; PMSF, phenylmethane-sulfonyl fluoride; DTT, 1,4-dithiothreitol; CD, circular dichroism; TLC, thin-layer chromatography; IEF, isoelectric focusing; $\mathbf{p l}$, isoelectric point amylases from animals (Gyémánt et al., 2009; Ueda et al., 2008), plants (Elarbi et al., 2009; Stamford et al. 2001) and terrestrial bacteria (Francis et al., 2002; Grupta et al., 2003; Zhang and Zeng, 2008), but less for marine bacteria amylase, especially the enzyme from microorganisms in deep-sea environment. Now that $71 \%$ of the earth's surface is covered by seawater with an average depth of $3800 \mathrm{~m}$, deep-sea environments have attracted much interest as niches of microbial life and microbial enzyme resources with considerable exploitation potential.

In our former study, a total of 98 heterotrophic bacteria were isolated from the sediments in the Southern Okinawa Trough and the diversity of their extracellular hydrolytic enzymes was studied (Dang et al., 2008). The results showed that stain K6-28-040, which was identified as Pseudomonas sp., had a higher amylase activity. In this paper, the amylase produced by Pseudomonas sp. was purified to homogeneity through a series of three steps 
consisting of ammonium sulfate precipitation, dialysis and gel filtration chromatography. At the same time, the properties of the enzyme with respect to $\mathrm{pH}$, temperature, $K_{\mathrm{m}}$ and $V_{\max }$ and degradation ability were also studied.

\section{MATERIALS AND METHODS}

\section{Materials}

Ethylenediaminetetraacetate (EDTA), ethylenebis(oxonitrilo)] tetraacetate (EGTA), sodium dodecyl sulfate (SDS), dimethylsulfoxide (DMSO), phenylmethane-sulfonyl fluoride (PMSF) and 1,4-dithiothreitol (DTT) were obtained from Sigma and used as supplied. Glucose, yeast extract, tryptone and agar were purchased from Oxoid Ltd. (Basingstoke, England). The other chemicals used in the preparation were all purchased from Sinopharm Chemical Reagent Corporation and were of analytical grade or higher grade.

\section{Microorganism and culture conditions}

The heterotrophic bacteria (CCTCC, AB 209216) were isolated from the Southern Okinawa Trough deep-sea sediment (Dang et al., 2008). The strain was grown on $2216 \mathrm{E}$ marine agar medium containing $5 \mathrm{~g} / \mathrm{l}$ peptone, $1 \mathrm{~g} / \mathrm{l}$ yeast extract, $0.01 \mathrm{~g} / \mathrm{l}$ ferric phosphate, $20 \mathrm{~g} / \mathrm{l}$ agar and stored at $4^{\circ} \mathrm{C}$. The production medium consisted of $2.00 \mathrm{~g} / \mathrm{l}$ starch, $3.99 \mathrm{~g} / \mathrm{l}$ peptone, $3.86 \mathrm{~g} / \mathrm{l}$ yeast extract, $0.33 \mathrm{~g} / \mathrm{l} \mathrm{CaCl}_{2}, 3.81 \%$ salinity and adjusted to $\mathrm{pH} 6.0$ with $\mathrm{HCl}$. The seed culture was cultivatied under agitation at $180 \mathrm{rpm}$ for $24 \mathrm{~h}$ $\left(35^{\circ} \mathrm{C}\right)$. The cell-free supernatant containing $\alpha$-amylase was harvested by centrifugation at $5000 \mathrm{~g}$ for $10 \mathrm{~min}$ at $4^{\circ} \mathrm{C}$ and used as the crude enzyme solution for purification.

\section{Amylase purification}

The crude enzyme solution was subjected to ammonium sulfate precipitation and the protein precipitating at $60 \%$ saturation was resuspended in $50 \mathrm{mM}$ phosphate buffer $(\mathrm{pH} \mathrm{7.0)}$ and dialyzed against the same buffer for $18 \mathrm{~h}$. The dialyzed solution was then applied to a Sephadex G-75 column and eluted with $50 \mathrm{mM}$ phosphate buffer ( $\mathrm{pH}$ 7.0). The active fractions were collected and concentrated using Amicon ultra centrifugal units (from Sigma, 5 $\mathrm{kDa}$ molecular weight cut-off, Cat. No. Z648019). Finally, the resulting enzyme preparation was desalted by dialysis. All the purification experiments were performed at $4^{\circ} \mathrm{C}$.

\section{Enzyme assay and protein determination}

Amylase activity was determined by modified Bernfeld method (1955). In brief, $1.5 \mathrm{ml}$ of $1 \%(\mathrm{w} / \mathrm{v})$ soluble starch solution made in $50 \mathrm{mM}$ phosphate buffer ( $\mathrm{pH} 7.0)$ was mixed with $0.5 \mathrm{ml}$ of enzyme. The reaction mixture was incubated at $35^{\circ} \mathrm{C}$ for $20 \mathrm{~min}$. The liberated reducing sugars were estimated by the dinitrosalicylic acid test (Miller, 1959). The colors developed were read at $540 \mathrm{~nm}$ on a UV-2450 (SHIMADZU, Japan). Calibration curve was constructed using glucose as the standard. To subtract the reducing sugars caused by the medium from experimental results, the experiments without the addition of starch were conducted and the measured sugar content was deducted from the assay. One unit $(U)$ of amylase was defined as the amount of enzyme releasing $1.0 \mu \mathrm{g}$ of glucose equivalent per minute under the assay conditions. The protein concentration was measured with bovine serum albumin as a standard (Sedmak and Grossberg, 1977). All measurements in this experiment were made in triplicate.

\section{Sodium dodecyl sulfate-polyacrylamide gel electrophoresis (SDS-PAGE)}

The SDS-PAGE analysis was performed under reducing conditions using NuPAGE 4 to $10 \%$ Bis-Tris mini gels (Invitrogen, U.S.A.), following the manufacturer's instructions. Protein bands were detected by staining with Brilliant Blue Coomassie G-250.

\section{Isoelectric focusing (IEF)}

The isoelectric point $(\mathrm{p} /$ ) of amylase was examined with the Rotofor IEF cell (Bio-Rad, U.S.A.) using Bio-Lyte ampholyte (pH 3.9-9.5, Cat. No.163-1112) to produce the necessary $\mathrm{pH}$ gradient. The amylase sample (18 ml) was loaded into the Rotofor cell and constant power $(10 \mathrm{~W})$ was applied with the system cooled to $4^{\circ} \mathrm{C}$. Initial voltage was $570 \mathrm{~V}$ and a plateau of $1100 \mathrm{~V}$ was reached after $4 \mathrm{~h}$. A total of 20 fractions were collected into separate vials, using a vacuum source attached through plastic tubing to an array of 20 needles. The amylase assay was measured for each of the Rotofor fractions, and $\mathrm{pH}$ values determined.

\section{Circular dichroism}

Circular dichroism (CD) experiments were preformed on PMS 450 spectropolarimeter (Biologic, France) with a $1 \mathrm{~mm}$ path length cell at $25^{\circ} \mathrm{C}$. The purified amylase sample was concentrated to $1.5 \mathrm{~g} / \mathrm{l}$ and the reference solvent was ultrapure water. The CD spectrum was recorded over a wavelength range of 190 to $250 \mathrm{~nm}$ with $1 \mathrm{~nm}$ resolution and $5 \mathrm{~s}$ of average time. Ultrapure water was used as a blank to correct the baseline. Results were expressed as the molar mean residue ellipticity $(\theta)$ at a given wavelength.

\section{Kinetic studies}

To obtain $K_{\mathrm{m}}$ and $V_{\max }$ for soluble starch, $2 \mathrm{ml}$ of $0.2,0.5,1,1.5,2,3$, $4,5,6$ and $7 \%(\mathrm{w} / \mathrm{v})$ soluble starch in $50 \mathrm{mM}$ phosphate buffer $(\mathrm{pH}$ 7.0) was mixed with $2 \mathrm{ml}$ of the purified amylase (the final enzyme concentration was $1.0 \mathrm{U} / \mathrm{ml}$ ), respectively and the mixture was incubated at $50^{\circ} \mathrm{C}$ for $20 \mathrm{~min}$ and the reaction was stopped immediately by heating at $100^{\circ} \mathrm{C}$ for $10 \mathrm{~min}$. $K_{\mathrm{m}}$ and $V_{\max }$ values were obtained from Lineweaver-Burk plot and expressed as the mean of the three different experiments.

\section{Chromatographic analysis of the starch hydrolysis products}

The starch hydrolysis products were subjected to thin-layer chromatography (TLC) with silica gel $60(20 \mathrm{~cm} \times 20 \mathrm{~cm}$, Merck, Germany) in a solvent system composed of chloroform/acetic acid/water $(60: 70: 10, \mathrm{v} / \mathrm{v} / \mathrm{v})$. The spots were visualized by spraying TLC plates with $\mathrm{H}_{2} \mathrm{SO}_{4} /$ methanol $(5: 95, \mathrm{v} / \mathrm{v})$ followed by heating at $120^{\circ} \mathrm{C}$ for $10 \mathrm{~min}$ (Hmidet et al., 2008).

\section{Effect of temperature on activity and thermal stability}

The optimum temperature of the enzymatic reaction was determined 
Table 1. Purification of amylase from marine Pseudomonas sp. K6-28-040.

\begin{tabular}{|c|c|c|c|c|c|}
\hline Purification step & $\begin{array}{l}\text { Total protein } \\
(\mathrm{mg})\end{array}$ & $\begin{array}{l}\text { Total activity } \\
\text { (U) }\end{array}$ & $\begin{array}{l}\text { Specific activity } \\
(\mathrm{U} / \mathrm{mg})\end{array}$ & $\begin{array}{l}\text { Purification } \\
\text { (fold) }\end{array}$ & $\begin{array}{l}\text { Yield } \\
(\%)\end{array}$ \\
\hline Crude enzyme solution & 69.3 & 1976 & 28.5 & 1.0 & 100 \\
\hline Ammonium sulfate precipitation & 21.8 & 1079 & 49.5 & 1.7 & 55 \\
\hline Gel filtration chromatography & 6.5 & 875 & 134.6 & 4.7 & 44 \\
\hline
\end{tabular}

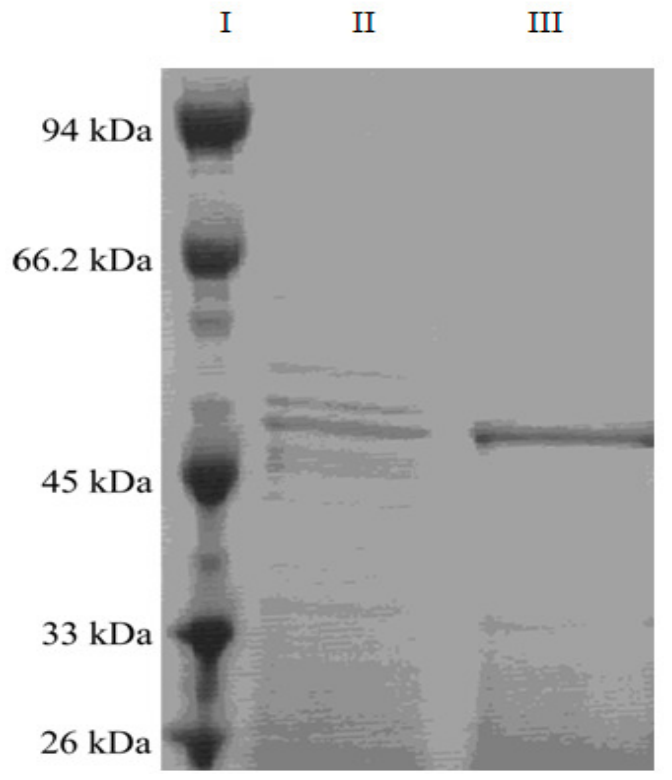

Figure 1. SDS-PAGE analysis of purified amylase. I, Molecular mass marker; II, crude enzyme solution; III, purified amylase.

in $50 \mathrm{mM}$ sodium phosphate buffer $(\mathrm{pH} 7.0)$ over a temperature range of 20 to $70^{\circ} \mathrm{C}$ for $30 \mathrm{~min}$. Thermal stability of the enzyme was examined by incubation of the purified enzyme in the same buffer at $25,30,35,40,45,50$ and $55^{\circ} \mathrm{C}$ for $2 \mathrm{~h}$. The remaining enzyme activity was then measured as described earlier.

\section{Effect of pH on activity and pH stability of amylase}

The optimal $\mathrm{pH}$ for amylase activity was determined at $50^{\circ} \mathrm{C}$ in 50 $\mathrm{mM}$ citrate buffer ( $\mathrm{pH} 4.0$ to 5.0 ), $50 \mathrm{mM}$ sodium phosphate buffer (pH 6.0 to 7.0), $50 \mathrm{mM}$ Tris- $\mathrm{HCl}(\mathrm{pH} 8.0$ to 9.0) and $50 \mathrm{mM}$ glycine- $\mathrm{NaOH}(\mathrm{pH} 10.0$ to 11.0). All $\mathrm{pH}$ values were adjusted at room temperature and the $\mathrm{pH}$ stability of the amylase was evaluated by determining the residue activities after $2 \mathrm{~h}$ incubation in the aforementioned buffers at $4^{\circ} \mathrm{C}$.

\section{Effect of chemical reagents on the enzyme activity}

The effects of metal ions on amylase were examined by determining the activities after $1 \mathrm{~h}$ incubation at $4^{\circ} \mathrm{C}$ in $50 \mathrm{mM}$ phosphate buffer ( $\mathrm{pH}$ 7.0) containing various metal ions at $5 \mathrm{mM}$. The activity assayed in the absence of metal ions was defined as control. The metal ions tested include $\mathrm{NaCl}, \mathrm{CuCl}_{2} \cdot 2 \mathrm{H}_{2} \mathrm{O}, \mathrm{CaCl}_{2}, \mathrm{HgCl}_{2}, \mathrm{MnCl}_{2}, \mathrm{CoCl}_{2} \cdot 6 \mathrm{H}_{2} \mathrm{O}$, $\mathrm{MgCl}_{2} \cdot 6 \mathrm{H}_{2} \mathrm{O}, \mathrm{ZnCl}_{2}, \mathrm{NiSO}_{4} \cdot 6 \mathrm{H}_{2} \mathrm{O}, \mathrm{SrCl}_{3} \cdot 6 \mathrm{H}_{2} \mathrm{O}, \mathrm{FeCl}_{3}$ and $\mathrm{AlCl}_{3}$.

The effects of protease inhibitors (SDS, EDTA, EGTA, PMSF, DTT and DMSO) on amylase activity were measured in the reaction mixture as described earlier with various inhibitors at a final concentration of $10 \mathrm{mM}$. The purified enzyme was pre-incubated with the respective compound for $10 \mathrm{~min}$ at $4^{\circ} \mathrm{C}$, followed by the standard enzyme assay as described earlier. The relative activity assayed in the absence of the protein inhibitors was regarded as $100 \%$.

\section{RESULTS AND DISCUSSION}

\section{Enzyme purification}

The purification of amylase is summarized in Table 1. Total amylase activity from the culture fluid of Pseudomonas sp. was $1976 \mathrm{U}$. The ammonium sulfate precipitation reduced the total enzyme activity by $45.4 \%$, but only gave an improvement of specific enzyme activity of 1.7 times. The effect of gel filtration chromatography was to decrease the total protein sharply from 21.8 to 6.5 $\mathrm{mg}$, but only to decrease the total enzyme activity by $19 \%$. The overall yield of $44 \%$ was obtained. All these results indicate that the ammonium sulfate precipitation is the main reason for enzyme activity loss in all the purification processes.

\section{Electrophoresis}

The isoelectric point of the amylase was found to be 7.5 to 7.8 , which is smaller than that of amylase from a deep-sea Bacillus isolate ( $p / 8.6$ ) (Hatada et al., 2006). To determine the structure and molecular weight of the enzyme, the SDS-PAGE analysis was performed under reducing conditions (Figure 1). Sodium dodecyl sulfate-polyacrylamide gel electrophoresis analysis showed a single band near $58 \mathrm{kDa}$. This molecular weight falls within the range of values (54 to $68 \mathrm{kDa}$ ) reported for purified raw-starch-digesting amylase from other sources (Ueda et al., 2008).

\section{Circular dichroism (CD) of amylase}

$C D$ is a valuable method for the analysis of protein 


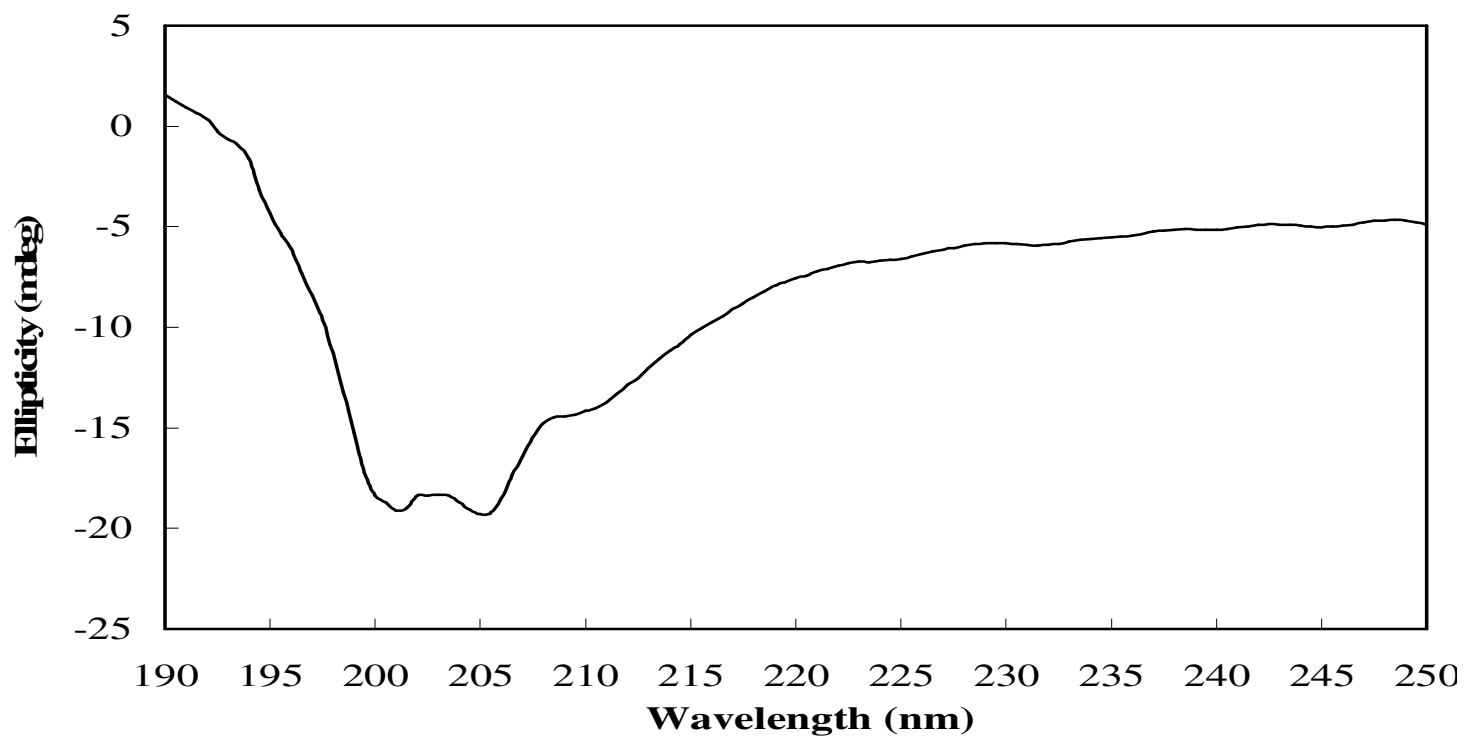

Figure 2. Circular dichroism (CD) spectrum of purified amylase sample.

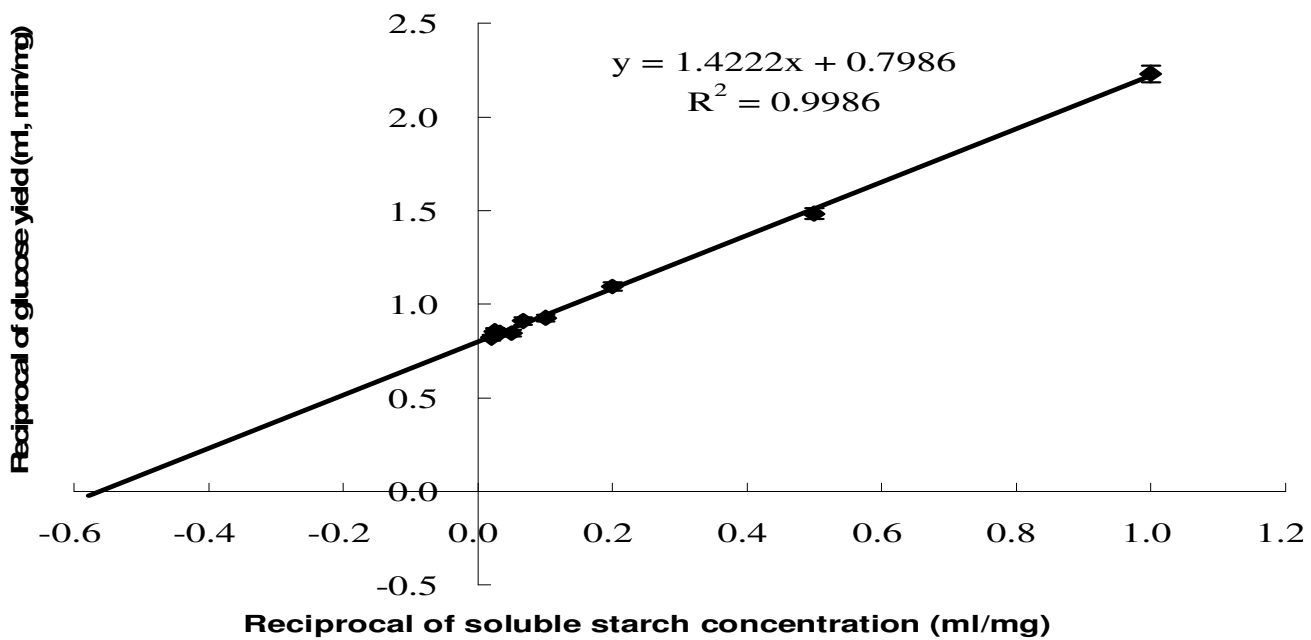

Figure 3. Lineweaver-Burk plot for $K_{\mathrm{m}}$ and $V_{\max }$ values of purified amylase in the different concentrations of soluble starch.

Secondary structure, and the far-UV CD spectroscopy from 190 to $250 \mathrm{~nm}$ was used to estimate the contents of the secondary structures in the purified amylase. The CD spectrum is shown in Figure 2. The theoretical values of $\alpha$-helix, $\beta$-shee and random coil were 28,32 and $40 \%$ (http://www.embl.de/ andrade/k2d/) (Chang et al., 1978; Yang et al., 1986), respectively.

\section{Kinetic parameters}

Lineweaver-Burk plots in Figure 3 shows that, apparent
$K_{\mathrm{m}}$ and $V_{\max }$ values of the purified amylase for soluble starch were $1.73 \pm 0.3 \mathrm{mg} / \mathrm{ml}$ and $1.24 \pm 0.02 \mathrm{mg} / \mathrm{ml} / \mathrm{min}$, respectively. These values were different with those of amylases from Aureobasidium pullulans $(5.75 \pm 0.3 \mathrm{mg} / \mathrm{ml}$ and $0.25 \pm 0.02 \mathrm{mg} / \mathrm{ml} / \mathrm{min}$ ) (Li et al., 2007)

\section{Chromatographic analysis of the starch hydrolysis products}

The $\alpha$-amylase was incubated with soluble starch $(1 \%$ $\mathrm{w} / \mathrm{v}$ ) and the hydrolysis products were separated and, 


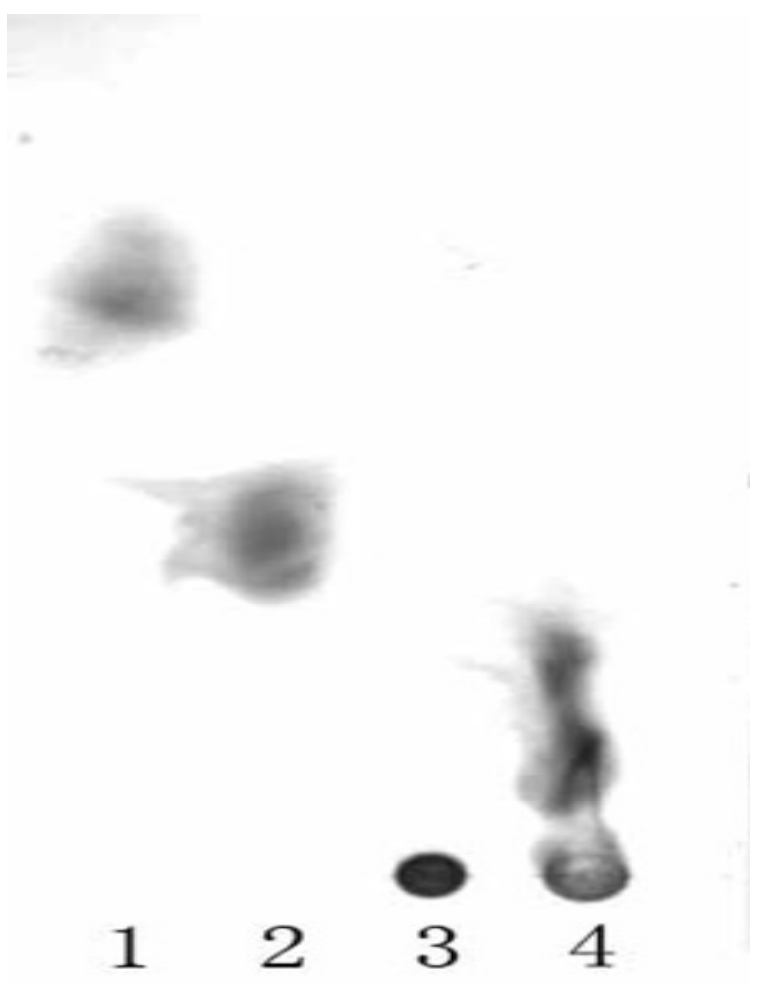

Figure 4. Thin-layer chromatography analysis of the main products from hydrolysis of soluble starch. Lane 1 , Glucose; lane 2, maltose; lane 3, unhydrolyzed soluble starch; lane 4, hydrolyzed soluble starch after $10 \mathrm{~h}$ incubation.

identified by TLC. As shown in Figure 4, the main hydro lysis products of soluble starch were large maltooligosaccharides after $10 \mathrm{~h}$ incubation. The size of the hydrolysis products was larger than maltose. These hydrolysis patterns revealed that amylase from Pseudomonas sp. K6-28-040 functioned as a typical a-amylase.

\section{Effect of $\mathrm{pH}$ and temperature on activity and stability of amylase}

The activity of amylase was measured in different buffers with $\mathrm{pH}$ ranging from 4.0 to 11.0 . As shown in Figure $5 \mathrm{a}$, the amylase exhibited optimum activity at $\mathrm{pH} 7.0$, which was higher than those of $\alpha$-amylase from Eisenia foetide (pH 5.5) (Ueda et al., 2008) and A. pullulans (pH 4.5) ( $\mathrm{Li}$ et al., 2007) . The enzyme was stable at the $\mathrm{pH}$ range from 5.0 to 10.0 with the highest activity at $\mathrm{pH} 8.0$ (Figure $5 b$ ). The effect of temperature on the amylase revealed that, the enzyme was optimally active at $50^{\circ} \mathrm{C}$ (Figure 6a), which was very close to that of $\alpha$-amylase from Bacillus subtilis $\left(55^{\circ} \mathrm{C}\right.$ ) (Najafi et al., 2005) and Bacillus sp. (40 to $50^{\circ} \mathrm{C}$ ) (Liu and $\mathrm{Xu}, 2008$ ). As Figure $6 \mathrm{~b}$ shows, a slight decrease of the amylase activity occurred when the temperature increased from 25 to $45^{\circ} \mathrm{C}$, but at $50^{\circ} \mathrm{C}$, it lost $51.9 \%$ of its original activity within $2 \mathrm{~h}$ of treatment and it was completely inactivated at $55^{\circ} \mathrm{C}$ in the same incubation period.

\section{Effect of chemicals on the activity of amylase}

The effect of chemical reagents on amylase activity was tested (Table 2). Among the cations used, $\mathrm{Ca}^{2+}, \mathrm{Mn}^{2+}$ and $\mathrm{Co}^{2+}$ were found to have a stimulating effect on the enzyme activity, whereas, $\mathrm{Cu}^{2+}, \mathrm{Hg}^{2+}, \mathrm{Fe}^{3+}$ and $\mathrm{Al}^{3+}$ were found to be strong inhibitors. In the presence of chelating agents, SDS, EDTA and DMSO weakly inhibited the enzyme activity. When the enzyme was assayed in the presence of EGTA, enzyme activity was reduced significantly with only about $10.4 \%$ activity left. All the results indicate that the purified enzyme was metalloenzyme (Ramirez-Zavala et al., 2004). In addition, PMSF 

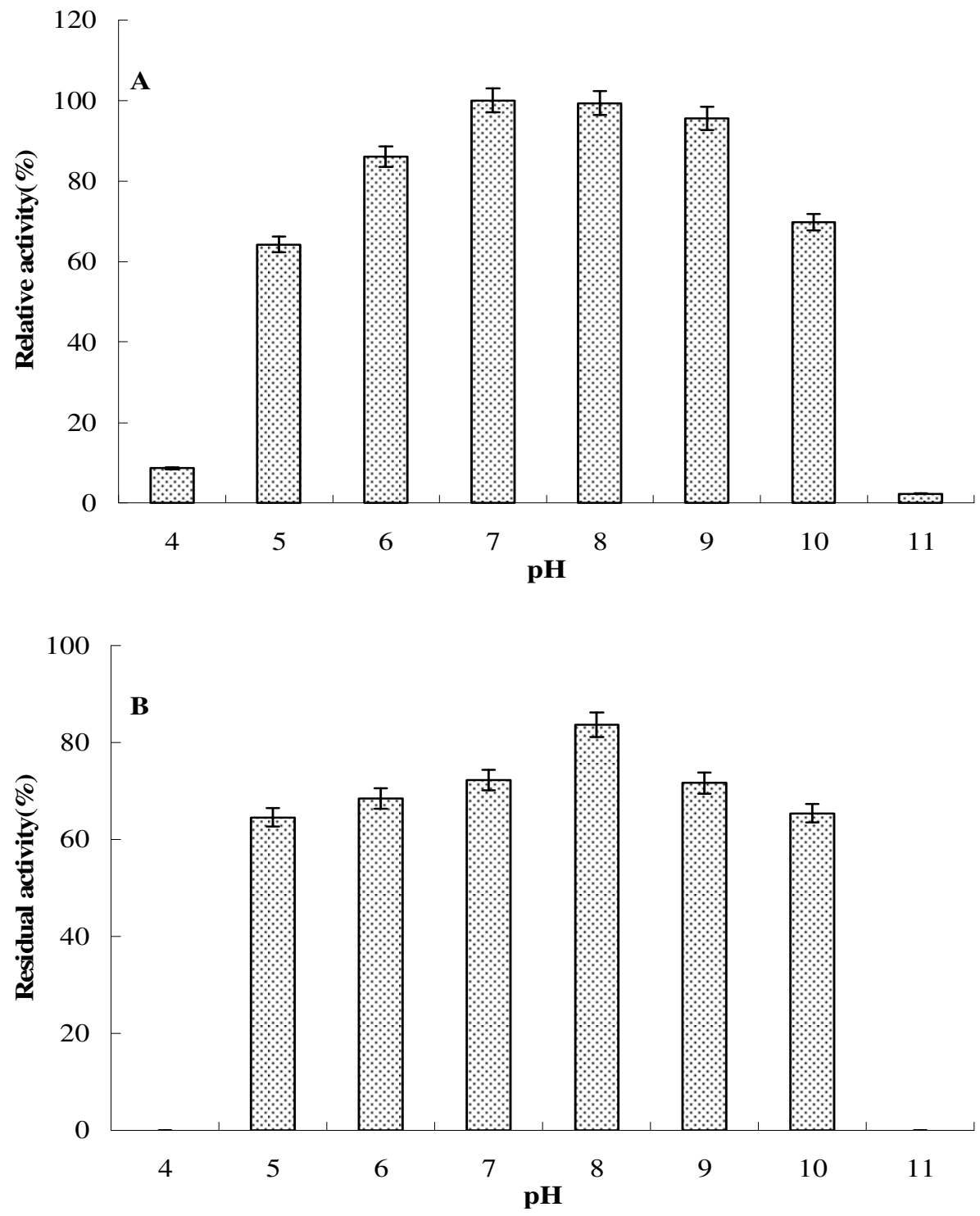

Figure 5. Effect of $\mathrm{pH}$ on amylase activity $(\mathrm{A})$ and stability (B). Enzyme activity was assayed at $50^{\circ} \mathrm{C}$ in $50 \mathrm{mM}$ citrate buffer ( $\mathrm{pH} 4.0$ to 5.0 ), $50 \mathrm{mM}$ sodium phosphate buffer (pH 6.0 to 7.0), $50 \mathrm{mM}$ Tris- $\mathrm{HCl}$ ( $\mathrm{pH} 8.0$ to 9.0), and $50 \mathrm{mM}$ glycine- $\mathrm{NaOH}$ (pH 10.0 to 11.0). For $\mathrm{pH}$ stability experiments, the enzyme was incubated in the aforementioned buffers for $2 \mathrm{~h}$ at $4^{\circ} \mathrm{C}$ and then, the remaining activity was determined.

and DTT were found to have no effect on the enzyme activity, indicating that, Ser residues were not essential for the enzyme active sites (Urek and Pazarlioglu, 2004).

\section{Conclusions}

In the present work, amylase was successfully purified from marine Pseudomonas sp. K6-28-040 and the purified enzyme was then, characterized by SDS-PAGE, iso- electric focusing and far-UV circular dichroism in addition to enzymatic activity. Further work is in progress to study the physicochemical properties of the enzyme, which may have significant implication for practical applications.

\section{ACKNOWLEDGEMENT}

The authors are grateful for the financial support of the Fundamental Research for the Central Universities. 

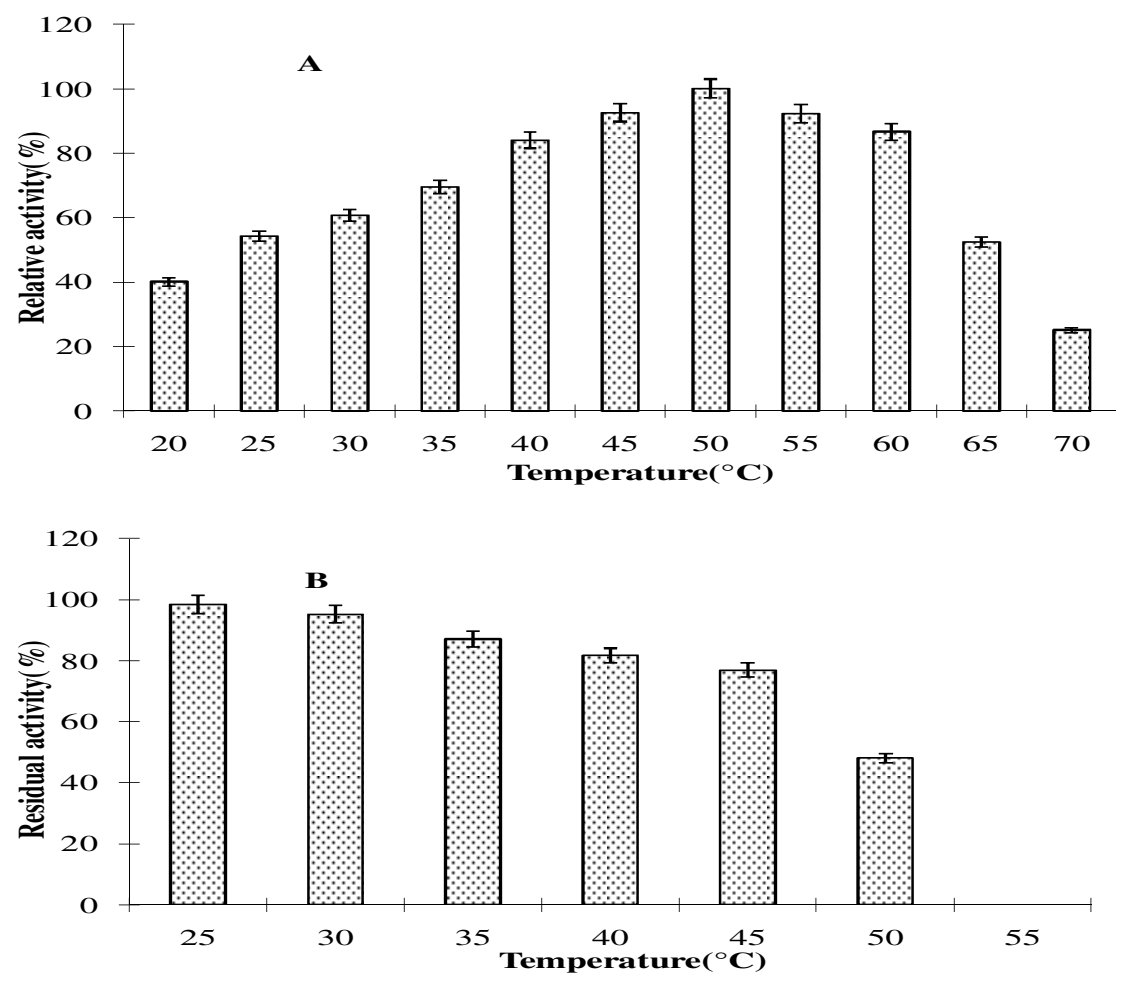

Figure 6. Effect of temperature on amylase activity (A) and stability (B). Enzyme activity was assayed for each temperature after an incubation period of $30 \mathrm{~min}$. For thermostability experiments, the enzyme extract was prewarmed at the indicated temperature for a $2 \mathrm{~h}$ period and then, the remaining activity was determined.

Table 2. Effect of various reagents on the activity of amylase.

\begin{tabular}{lcc}
\hline \multicolumn{1}{c}{ Reagent } & Final conc. (mM) & Relative activity (\%) \\
\hline Control & - & $100 \pm 1.8$ \\
$\mathrm{Na}^{+}$ & 5.0 & $101.5 \pm 2.0$ \\
$\mathrm{Cu}^{2+}$ & 5.0 & $47.2 \pm 0.4$ \\
$\mathrm{Ca}^{2+}$ & 5.0 & $117.1 \pm 3.5$ \\
$\mathrm{Hg}^{2+}$ & 5.0 & $35.6 \pm 1.6$ \\
$\mathrm{Mn}^{2+}$ & 5.0 & $118 \pm 2.3$ \\
$\mathrm{Co}^{2+}$ & 5.0 & $143.7 \pm 3.8$ \\
$\mathrm{Mg}^{2+}$ & 5.0 & $98.8 \pm 2.2$ \\
$\mathrm{Zn}^{2+}$ & 5.0 & $80.7 \pm 2.1$ \\
$\mathrm{Ni}^{2+}$ & 5.0 & $90.5 \pm 4.0$ \\
$\mathrm{Sr}^{3+}$ & 5.0 & $82.6 \pm 4.1$ \\
$\mathrm{Fe}$ & 5.0 & $55.8 \pm 3.7$ \\
$\mathrm{Al}^{3+}$ & 5.0 & $46.2 \pm 2.4$ \\
$\mathrm{SDS}$ & 10.0 & $91.2 \pm 0.6$ \\
EDTA & 10.0 & $82.1 \pm 1.0$ \\
EGTA & 10.0 & $10.4 \pm 0.8$ \\
PMSF & 10.0 & $99.4 \pm 0.6$ \\
DTT & 10.0 & $99.7 \pm 0.3$ \\
DMSO & 10.0 & $91.4 \pm 1.3$ \\
\hline
\end{tabular}

Mean \pm SE for triplicate determinations. 


\section{REFERENCES}

Bernfeld $P$ (1955). Amylases, $\alpha$ and $\beta$. Methods Enzymol. 1: 149-158. Bhat MK (2000). Cellulases and related enzymes in biotechnology. Biotechnol. Adv. 18: 355-383.

Chang CT, Wu CC, Yang JT (1978). Circular dichroic analysis of protein conformation: inclusion of the $\beta$-turn. Anal. Biochem. 91: 13-31.

Dang HY, Zhu H, Wang J, Li TG (2008). Extracellular hydrolytic enzyme screening of culturable heterotrophic bacteria from deep-sea sediments of the Southern Okinawa Trough. World J. Microbiol. Biotechnol. 25: 71-79.

Elarbi MB, Khemiri H, Jridi T, Hamida JB (2009). Purification and characterization of $\alpha$-amylase from safflower (Carthamus tinctorius L.) germinating seeds. C. R. Biol. 332: 426-432.

Fogarty WM, Kelly CT (1990). Microbial enzymes and biotechnology. Elsevier Science Publishers, London, UK.

Francis F, Sabu A, Nampoothiri KM, Szakacs G, Pandey A (2002). Synthesis of $\alpha$-amylase by Aspergillus oryzae in solid-state fermentation. J. Basic Microbiol. 42: 320-326.

Grupta R, Gigras P, Mohapatra H, Goswami VK, Chauhan B (2003). Microbial a-amylase: a biotechnological perspective. Process Biochem. 38: 1599-1616.

Gyémánt G, Zajácz Á, Bécsi B, Ragunath $C$, Ramasubbu N, Erdodi $F$, Batta G, Kandra L (2009). Evidence for pentagalloyl glucose binding to human salivary $\alpha$-amylase through aromatic amino acid residues. Biochim. Biophys. Acta. 1794: 291-296.

Hatada Y, Masuda N, Akita M, Miyazaki M, Ohta Y, Horikoshi K (2006). Oxidatively stable maltopentaose-producing $\alpha$-amylases from a deep-sea Bacillus isolate, and mechanism of its oxidative stability validated by site-directed mutagenesis. Enzyme Microb. Technol. 39: 1333-1340.

Hmidet N, Bayoudh A, Berrin JG, Kanoun S, Juge N, Nasri M (2008). Purification and biochemical characterization of a novel a-amylase from Bacillus licheniformis $\mathrm{NH} 1$ Cloning, nucleotide sequence and expression of amyN gene in Escherichia coli. Process Biochem. 43: 212-214.

Kandra $L$ (2003). $\alpha$-Amylases of medical and industrial importance. J. Mol. Struct. 666: 487-498.

Kirk O, Borchert TV, Fuglsang CC (2002). Industrial enzyme applications. Curr. Opin. Biotechol. 13: 345-351.
Li HF, Chi ZM, Wang XH, Duan XH, Ma LY, Gao LM (2007). Purification and characterization of extracellular amylase from the marine yeast Aureobasidium pullulans $\mathrm{N} 13 \mathrm{~d}$ and its raw potato starch digestion. Enzyme Microb. Technol. 40: 1006-1012.

Liu XD, Xu Y (2008). A novel raw starch digesting a-amylase from a newly isolated Bacillus sp. YX-1: Purification and characterization. Bioresour. Technol. 99: 4315-4320.

Miller GL (1959). Use of dinitrosalicylic acid reagent for determination of reducing sugar. Anal. Chem. 31: 426-428.

Najafi MF, Deobagkar D, Deobagkar D (2005). Purification and characterization of an extracellular $\alpha$-amylase from Bacillus subtilis AX20. Protein Expr. Purif. 41: 349-354.

Ramirez-Zavala B, Mercado-Flores Y, Hernadez-Rodriguez C, Villa-Tanaca L (2004). Purification and charaterization of lysine aminopeptidase from Kluyveromyces marxiamus. FEMS Microbiol. Lett. 235: 369-375.

Sedmak JJ, Grossberg SE (1977). A rapid, sensitive and vertile assay for protein using Coomassia Brilliant Blue G250. Anal. Biochem. 79: 544-552.

Stamford TLM, Stamford NP, Coelho LCBB, Araújo JM (2001). Production and characterization of a thermostable $\alpha$-amylase from Nocardiopsis sp. endophyte of yam bean. Bioresour. Technol. 76: 137-141.

Ueda M, Asano T, Nakazawa M, Miyatake K, Inouye K (2008). Purification and characterization of novel raw-starch-digesting and cold-adapted $\alpha$-amylases from Eisenia foetida. Comp. Biochem. Phys. A 150: 125-130.

Urek RO, Pazarlioglu NK (2004). Purification of partial characterization of manganese peroxidase from immobilized Phanerochaeto chrysosporium. Process Biochem. 39: 2061-2068.

Yang JT, Wu CC, Martinez HM (1986). Poly (L-lisine) at different pH and temperature. Methods Enzymol. 130: 208-271.

Zhang JW, Zeng RY (2008). Purification and characterization of a cold-adapted a-amylase produced by Nocardiopsis sp. 7326 isolated from prydz bay. Antarctic Mar. Biotechnol. 10: 75-82. 